\title{
Plight of Widows in Hindu Religion (A Social Critique to Deepa Mehata's Film Water)
}

\author{
Ramesh Prasad Adhikary
}

Tribhuvan University, M.M. Campus, Nepal

\begin{abstract}
This research paper is focused in Deepa Mehta's Film Water to study the plight of Hindu widows. As the tradition of Hindu society, widows are compelled to adopt the widow system. Chuyia, the eight-year-old protagonist is sent to a Bidhuwa Ashram in Benaras because of her widowhood. The exploitation of child-marriage in the grip of patriarchal culture of widowhood, and the rejection of Chuyia to accept her widowhood is presented in the film. Kalyani, the second young widow in the ashram, revolts against such inhuman culture and decides to get married. She is forced to act as a 'prostitute' in the house of bourgeois. Chuyia is also sexually exploited by bourgeois. Through a qualitative work using Feminism framework, I offer a powerful critique on the Hindu Widow System based on Deepa Mehta's Water, by not only showing its religious, bourgeoisie, and patriarchal underpinnings that treat widows to the level of living deeds, but also shows the possibility of subverting such dogmas by raising the issue of widow marriage. The conclusion is that the film Water by Deepa Mehta presents the predicament of Indian Hindu widows. It shows the inert life of the group of widows obliged to live in a widow house neglected from society because of Hindu widow system
\end{abstract}

Keywords: Widow, Patriarchy, Hinduism, Prostitution, Stereotype, Tradition

\section{INTRODUCTION}

This research paper focuses on the film Water which portrays the evil widow tradition and the plight of Hindu widows. Deepa Mehta's Water is a film which presents the plight of Indian Hindu widows of 1930s. It also presents colorless life of widows who are obliged to live in a widow house being alienated and hated by society. They are taken worthless without a husband. They have to struggle to survive by begging and also have to involve into prostitution activities.

In the film Mehta presents how girls and women are deeply victimized by the Hindu system regarding the widowhood. The protagonist like Chuyia and Kalyani and others were compelled for child marriage and when their husbands died, they had to face the evil destiny of exploitation. The religious norms and evil tradition of Hindu culture forced widows to live the life full hatred being detached from society and spending the absurd life in widow ashram. Rich Brahmins exploited and commodified widows. Chuyia and Kalyani unwillingly turned to prostitution in order to fulfill the poverty and run the ashram.

In the film, the setting is 1938 Benaras, a city in India where widow houses still exist. It is set during the period of the British Raj or British Indian Empire when India was still under colonial rule by the British. Child marriages of young girls were common in certain parts of India at that time. When a 
man from an orthodox Hindu family died, his young widow would be forced to spend the rest of her life in an institution for widows in order to make amends for the sins from the previous life which supposedly caused her husband's death. Deepa Mehta adopts the very notion of widowhood as a subject matter for her film Water. She focuses on the abuse of widows in India.

Mehata's film Water begins with the life of eight year old Chuyia, a child bride whose husband dies and she is left in widow's house in Benaras. There she is expected to spend the rest of her life in the process of renunciation. Chuiya as she is a child she does not know about widow system, in spite of that she is forced to live the life of widows adopting the ritual of widowhood. She begins to spend the life of widow by adopting the life of self denial thinking that she must not have to live in the ashram for a long; one day she will go to her home. The arrival in the ashram changes the life of widows especially Kalyani and Shakuntala who begin to question against injustice widow system.

Based on the movie, once widowed, a woman ceased to exist as a person; that she is no longer either daughter or daughter in law. There is no place for her in the community and she is viewed as a threat to society. A woman's sexuality and fertility, which is so valuable to her husband in his lifetime, is converted upon his death into a potential danger, as if they were the mortality of the community.

The original meaning of Sati which is a Sanskrit word is simply a faithful and devout wife, and the term denotes especially to the woman who immolated herself. Though Sati is considered as a Hindu custom, the women, known as sati in Hindu religious literature, did not commit suicide in their dead husband's pyre. The first woman known as sati was the consort of lord Shiva. She burnt herself in the fire as protest against her father who did not give Shiva the respect she thought he deserved. While burning herself she prayed to reborn again as the new consort of Shiva, which she become and her name in the new incarnation is Parvati. In this way the word sati (Suttee in English) comes to exist which is described as Hindu custom in India in which the widow is burnt on her dead husband's pyre in the process of renunciation.

Sati dies as a wife, eschewing the ill fated, ominous, and impure state of widowhood. The religious dogmas believe that through her sacrifice the sati preserved the bodily and spiritual unity of the couple, affording the Hindu marriage sacrament, which is ultimate and the truest expression. Moreover, it is believed that a woman dying on the funeral pyre of her husband can enjoy eternal bliss in heaven and self immolation is the only meritorious course that a virtuous widow can follow. So the term denotes the wife who performed the supreme act of fidelity by sacrificing herself which is an effort of transcending the state of widowhood. The situation becomes more exacerbated in the case of childhood marriage. This paper shows that by the film Water, Mehata has presented the social critique of the then society. By presenting the pathetic condition of widows and their rebellion against the Hindu social tradition, the film portrays social reality. This research paper makes its analyses from feminist point of view to make public aware about the tradition of Hindu religion.

\section{LITERATURE REVIEW: HINDU WIDOW SYSTEM AND THE FILM}

Different critics have given their criticism regarding Hindu widow tradition and culture along with the film Water. In "Can the subaltern speak?" Spivak describes the act of sati as follows:

The Hindu widow ascends the pyre of the dead husband and immolates herself upon it. This is widow sacrifice. The rite was not practiced universally and was not caste or class-fixed. 
Here, according to Spivak the subordination of women to the superstructure of male domination includes the very denial of breath and life; the subaltern woman (widow) is not expected to die to preserve the honor of the dead husband, but is indeed imagined to desire death. The death of sacrificed is predicated on the death of her husband which makes clear that women has no self identity.

On the other side, child marriage is one of the cultural practices in Hindu society where the children are married in their childhood, without knowing the exact sacraments of marriage. As seen on the movie, once the girls' husband dies, they are compelled to follow the widow system without knowing what is meant to be widow. So, the exploitation of child, reflected on our art of interest, can be seen in traditional Hindu society. Regarding the child marriage and the exploitation of child because of Hindu sati custom, Anjana Kant (2003) has defined the culture of widowhood where she writes that the position of woman in the words of Shastri appeared to be as follows:

The enforced child-marriages, the exposure of the female children by throwing them at the junction of the Ganges and the sea, the violence used to make women follow the sati rule and, thus, end their miserable existence. (57)

Here, Kant opines that women have to renounce their life by following the custom of sati. They are regarded as an object as they are obliged to perform the traumatic act by burning themselves in the pyre of their husband's body and end their miserable existence. Moreover, the girl children are also victim of the system as they were thrown at the junction of the sea. Being fed up with the culture of sati women made a wish that they had never been born as a woman.

In Hindu tradition, widows have to detach from the society and live in an institution of widows. Widows should shave their head and wear white custom. They cannot eat sweets and delicious food. They cannot see their face in mirror nor should they look beautiful. They also should not use any perfumes and their dress should be coarse and dirty. The use of any kind of conveyance is prohibited. And, also, she cannot rest in the bed. All of above experiences are well reflected in the movie.

The most sacred of Aryan scriptures are the Vedas, and the Rig Veda, the oldest Veda, explicitly sanctions the custom of sati for widow. The following famous 'Sati Hymn' of the Rig Veda was (and still is) recited during the actual immolation of the widow (Jamison \& Joel, 2014). Rig Veda X.18.7 "Let these women, whose husbands are worthy and are living, enter the house with ghee (applied) as corrylium (to their eyes). Let these wives first step into the pyre, tearless without any affliction and well adorned." — [ Rig Veda X.18.7] (Jamison \& Joel, 2014).

Traditionalism and religion play the dominant role in Hindu society which is regarded as the great force. Women are the torch-bearers of religion and play an important role in preserving both religion and culture. Women are obliged to adopt widow system because of the tradition and culture of widowhood. Moreover they have no other option rather than embracing the system as it is very obvious to say that patriarchy has effected in its worst form to Hindu women. In other words patriarchy and religion is interrelated to each other. Religion is the outcome of patriarchy and vice versa. The religious norms and values are made by the male authorities that are to be followed by women.

In the book Women and Religion by Renavikar (1998), Margaret Anderson quotes: "Sexism in traditional religious teachings and exclusion of women from positions of religious 
authority indicate that religions authority indicate that religion is a powerful source for the subordination of women in society" (33). Anderson views that "sex" play the crucial role in the society. The religious value is itself patriarchy in the sense that it is constructed by men authorities, where women are excluded from that, which calls the subordination of women in society. Men they themselves set an ideology about women which is seen in The RigVeda Sacred texts.

The RigVeda Sacred texts declares that the widow should remain chaste, though their husband dies, by adopting the concept of monogamy. However, there is not any passages in The RigVeda Sacred texts that declares that man also should remain chaste after their wife is dead. The Hindu religious values are set by the men themselves where they impart that widows should not get remarried but men can get remarried. Thus, the concept of polygamy is set for men by men themselves.

Similarly, another protagonist of the film named Kalyani is greatly affected by the widow system of the society. She is only the stunning young widows among other who is forced to prostitution. As widows are regarded as family burden in their house so they were sent to Bidhuwa Ashram. And to run ashram, they often beg for money sitting on the temple and often turn on prostitution. And it is regarded as the tradition in the society. Stephen Hunter (2006), a critic sets forward that it has become duty of widows to perform such act and quotes:

Even as reform seems close at hand, traditional obligations impose tragedy upon the ashram [as] one of the duties of the widows is to perform the occasional act of the prostitution, to keep the economic enterprise afloat: thus Kalyani is selected for job [...] Even worst is the fate that awaits the irrepressible Chiyia. (C 1 )

The film shows the commodification of widows. Kalyani is a character who is forced to be commodified in the hands of rich Brahmins they are the bourgeoisie of the society. The people of the society are themselves pretender in the sense that on the one hand, they regard widows should remain chaste as declared by religious books but men themselves violates the chastity of widows by sleeping with them. William Arnold (2006), a movie critic, regarding the patriarchal tradition of society writes that; "It is a tragic love story that fearlessly attacks the enslaving hypocrisy of patriarchal tradition that has developed over thousands of years of socio-economic imperatives and now disguise itself as religion" (5). Arnold here, states that socio-economic imperatives are the outcome of patriarchal tradition and widows are interiorized in the society because of these imperatives.

Jennette Catsoulis (2006) views that widows are institutionally oppressed because of patriarchal imperatives. Water is fine film about the institutionalized oppression of an entire class of women and the way patriarchal imperatives inform religious belief Serene of the surface yet roiling underneath, the film by neatly parallels the plight of widows under Hindu fundamentalism to that of India under British colonialism. Though Gandhi and his followers are as insistent background presence the movie is never didactic, trusting the simply rhythms of the women's lives to tell the story. (19)

In this way, different critics have given their views regarding women and widow oppression in the society and conventionalized widow system is the root cause for this. This research is focused on Deepa Mehta's film which not only presents a powerful critique on Hindu Widow System by showing its religious, bourgeoisie and patriarchal underpinnings that treat widows to the level of living deeds but also shows the possibility of subverting such dogmas by raising the issue of widow marriage. These things are untouched by the aformentioned critics. 


\section{THEORETICAL METHODOLOGY: FEMINISM}

In this research paper, the researcher has used feminism as a tool to interpret the film and to redefine female identity.

The term "feminism" coined from the early period of nineteenth century. Feminism as a literary discourse came after 1960s. In its broadest concept, feminism continues to be closely interrelated with the movement by political feminism for social, economic, and cultural freedom. Generally, it advocates women's right based on a belief in the equality of the sexes politically and biologically from a women centered point of view and it refuses to accept the cult of masculine Chauvinism and superiority that reduces women to sex object, a second sex, and a submissive to the man. Feminism seeks to eliminate the subordination, oppression, inequalities and injustices of women which they suffer because of their sex, and it further defends equal rights for women in a political, economic, social, psychological, personal and aesthetic sense. So, feminism is associated with the women's movement or the feminist movement culture is a transformational social movement that focuses on changing the mostly institutional and social attitudes.

Feminism came into practice to eradicate the against women's marginalization in all social forms of knowledge and practice. This happens because our society, civilization and practices all are pervasively patriarchal, that is male centered, which is controlled, organized and conducted in such a way that it subordinates women in all cultural domains such as family, religious, political, economic, social, legal and so forth. By this cultural process the masculine in our culture has come to be widely defined as active, dominating, adventurous rational, creative, and the feminine by systematic opposition to such traits. Men are always empowered with the sense of "I am man she is woman, I am strong she is weak, I am tough, she is tender. I am rely sufficient, she is needful" (Ruth 54, 1990).

It is the patriarchal social order which subjugates women folks to a second class or even third class citizenship. Here, women are projected as the 'other' subordinate being. Moreover, women are not regarded as an autonomous being; they are always identified by, with men. In her book The Second Sex, Beauvoir (1974) states, "Thus, humanity is male and man defines woman not as herself but as relative to him, she is not regarded as an autonomous being." (XVIII). She views that, women are always takes as relative being, they are introduced with relation to their father, husband or son. Regarding the patriarchal traditions Elise Boulding writes:

Patriarchal ethics brings in different kinds of socialization practices for the male and female in the family which ultimately lead to turn the male child into an 'oppressor' and the female child into a victim when they become adults. At the root of such oppressions against women is the reality that women are taken as 'objects' of both discriminations are violence of men. (Sinha 23)

Boulding holds a belief that patriarchy is the root cause for bringing discrimination in the society between sexes and subordination of women by men.

In this way feminism emerged as a reaction for the patriarchy and oppression of women in different field of the society, and it aims the quality between all genders. Not only in the western society but also all over the world including Third World Countries, women began to seek their hidden identity and speak for their rights in the patriarchal society. 
Women of third world countries are enforced to follow the tradition. The status of women in the society is no more than that of a mute animal. For example, women are obliged to follow the hierarchical social systems where they cannot find their respectable position. Regardless of caste, class or religion women are differentiated as secondary objects. The society keeps them aloof from social matters like decision making, participating in political matters, problem solving, social and familiar discussions and in financial issues. She even does not have right to make her own decision as she is deprived by tradition. As can be seen in Suguna Paul(1986) whose essay defended the women's right:

Women have been suppressed under custom and have for which man was responsible and in shaping of which she has no hand... Woman has as much right to shape her destiny as man has to shape his...It is up to men to see that they enable them to realize their full status and play their part as equal as men. (44)

Here, Paul views that because of men made tradition, women cannot speak for their desires in the society. She also has right of human being to shape her destiny and it is very men who must enable them (women) for having equal rights and opportunities in the society.

Marriage is regarded as an institution of enslavement, where women are slaves of their husband, where Uma Narayan (1997) wrote that reported:

Marriage is an oppressive institution for many women is something that predates my explicit acquisition of a feminist politics, and is something I initially learned not from books but from Indian women in general and my female relatives in particular. (9)

Here, Narayan holds a belief regarding marriage that it is an institution in which women work as slaves or workers for their husbands and husbands are regarded as the owners or masters of the marriage institution.

While saying, it may seem biased to go against the tradition of the nation. But feminists opine that the tradition is patriarchal and made in hierarchal order which is just a construction that subordinates women in a great extent, which is very true as seen in society, such tradition should be change. Narayan (1997) views that third world feminist need to be particularly alert to how much relatively uncontested change is needed for the better improvement of women and quotes, "we need to re-describe and challenge this picture of "Unchanging traditions" that supposedly are only now in danger of betrayal as a result of feminist instigation" (25).

Moreover, the people's notion about the proper role of women in the home and society and the social restrictions on women are all rooted in religions conception. Moreover, the religious scriptures and The RigVeda Sacred texts have influenced the status of women. The passage in the RigVeda declares that "the women are very fickle" (qtd. in Altekar 319). There is always misrepresentation of women in the religion's literature or scriptures, for example in India famous literature Mahabharata, it is told that "sensual enjoyment is the sole aim of women's existence" (320). Hence, women are always taken as a means of enjoyment.

Thus, the widow system is just violence against women. The concept of violence against woman here does not include only physical assault on her, but also physical and mental torture, harassment, exploitation, discrimination, which she has to undergo for being a woman. The state of widowhood represents the "climax of violence against women in our society. A widow in Hindu society has to undergo various kinds of socio-religious, cultural oppression as well as economic hardship" (Sinha 121). 
In this way, conventionalized tradition and culture is the reason behind exploitation of women in its worst form. Indeed, feminism has often focused upon what is absent rather than what is present, reflecting concern with the silencing and marginalization of women in a patriarchal culture; a culture organized in the favor of men, where their (women) existence in the society is always inferior to man. Feminism tries to minimize the oppression of women caused by the patriarchal tradition and culture, and seeks the equal rights and opportunities between men and women.

\section{ANALYSIS OF MEHTA'S WATER}

In the film Water, Deepa Mehta presents an issue regarding widowhood where the widows are forced to live a detached life adopting Hindu widow system. Following the system of widowhood, widows live the life of self denial in the widow house known as Bidhuwa Ashram.

The film examines the plight of group of widows forced to live into poverty at a temple in the holy city of Benaras. The women are sent here to expiate bad karma as well as to relieve their families from financial and emotional burdens. The gloom setting of the film explores the unhappiness of the widows. Plight of widows represents the worst form of discrimination against women in India. Superstitious families say widows are bad luck and blame for the death of their husband. The film illustrates widows struggle to survive and shows the rituals of widowhood.

All the widows live in the ashram as homelessness and lack of parent's love and affection. The ashram is a melancholy place with old widows. Mehta presents Chuyia and Kalyani as protagonist s and shows the exploitation of these characters along with others like Shakuntala and Patirajii (Bua), because of the tradition of the widowhood.

Water follows the life of eight year old Chuyia, a child bride abandoned at widow's house in Benaras after the death of her husband. There, she is expected to spend the rest of her life in penitence. She does not want to accept her fate of widow and becomes catalyst for change in the lives of widows, but she is forced to live the life of widow because of the widow system. She even does not know when marriage occurred and what it means to be a widow, which is realized in the conversation between Chuyia and her father:

Father: Do you remember getting married?

Chuyia: No.

Father: Your husband is dead. You are a widow now.

Chuyia: For how long, father?

These lines depict the exploitation of child Chuyia by the culture of child marriage and widowhood. The eight year old Chuyia does not know that she was a married girl but now she is a widow. She also does not know that she has to adopt the very widow system which is amalgation of tradition, culture and religion. When her father tells that she is widow now, in her innocence she asks the duration of remaining widow. Without knowing any marriage custom and what it means to be a wife, without having any compassion and love towards her husband, she is compelled to live the life of a widow imposed by tradition. Her question about the span of being widow makes her father dumb as he cannot answer her question.

In the very beginning of the film, Chuyia's husband dies, but she does not react on his death. Actually she was married to a man of the mid fifties and after his death she follows the rituals of 
widowhood, as her mother- in -law smashes her red bangles. She is provided white cloth by taking of her skirt and blouse as Hindu widow system does not permit widows to wear stitched clothes. The barber shaves her head. Her father watches her young daughter performing an agonizing ritual. Chuyia does not know why her head is shaved and why she is wearing white dhoti. Chuyia, while shaving her head curls her toes which symbolizes mute protest. It is enforced by the belief that if the widow does not shave her head every drops of water that falls upon the hair, pollutes her husband's soul.

Widows are regarded as burden of family and society with a belief that they will bring misfortune for rest of their (widows) family. So, all the women whose husbands die are sent to the widow ashram in Benaras. They live rest of their life without having any contact with their families and society. When Chuyia first goes to bidhuwa ashram with her father and mother in law, she is ignorant of the fact that she is going to be left in ashram forever by her father. She peeps in ashram and she is afraid of the appearance of two of the widows staring at her. Then, she runs out and asks her father to go back:

Chuyia: Let"s go home father?

Father: This is your home now.

The above dialogue precisely conveys that after being widow, the tradition does not allow Chuyia to live with her family. Chuyia does not like the ashram at her very sight so she pleads to return back from that place but her father says that the very widow ashram is her home after her husband's death. When Chuyia listens that widow house is her home, then she innocently asks, "Where's Ma?" She thinks that in the house (ashram) she will live with her father and mother.

Deepa Mehta, in the film presents the society guided by patriarchal norms and values. There is a system regarding widowhood and all women whose husband dies have to follow the very system. The tradition that she shows regarding widowhood is very rigid and inhuman. Every religious dogma and value have constructed the ideology of people in the society. Moreover, Women also follow the culture of widowhood thinking that it is their duty to obey the culture. The character named Madhumati is domineering of the widow house. She is guided by cultures and traditions of the society. She is very hypocrite, fat and pompous lady in her seventies. As she herself is a widow and thinks widows have to adopt the widow system by living the life of chastity and self denial in the ashram. She believes in the religious scriptures and books.

Mehta presents her character Chuyia as a victim of widow system. Though she is innocent and does not know about the culture of widowhood, Mehta makes Chuiya to utter such dialogue which criticizes and protests against the dehumanization nature of tradition towards women. When Chuyia listens to Madhumati saying her (Chuyia) life as a half dead because of her husband's death she gives a precise answer in her low voice, "Because she is half alive." The line makes it clear that though widow is regarded as half dead person doomed to live in one corner, still has half life. The people of the society do not think that widows are also human beings and get hurt by animalistic behavior towards them.

In the film, culturally widows are treated as inferior beings. After being widow, culture denies them to talk with other people of the society especially with any man. They even cannot touch other person in the society as they are regarded impure. Widows also cannot run like other person. Overall, widows should live the life of oppressed and suppressed in the society. The dialogue by woman to Kalyani hints about the false assumption towards widows as she says, "What are you doing? Widows should not run around like unmarried girl. You have polluted me? I have to bathe again." The line of woman conveys the attitude of the society towards widows. When Chuyia runs after the dog Kalu to catch it, Kalyani follows her saying not to run after it, it will come back and on the very time she comes to 
give a dash to woman. Woman who is guided by the patriarchal tradition of the society feels herself impure by the very touch with Kalyani and says immoral to her for touching her (woman) and running like unmarried girl. Widows are regarded as filth and pollution as woman says that she has to get bathe again because Kalyani polluted her.

Shakuntala is the most enigmatic widow. She is quiet and reserved widow among other widows. She believes in religious scriptures and is caught between her hatred of being widow and her fear of not being a sincere, devote widow. She is devoting Hindu widow who listens the priest reciting the scriptures to the pilgrims. Moreover, she herself reads the scriptures and tries to live as pure as possible. She becomes a mother-figure for Chuyia. She cares about Chuyia, Kalyani and Bua. Mehta presents such a character like Shakuntala to show the faithfulness and fidelity of wives towards their husbands. Though Shakuntala follows widow system, in her heart she feels living a life of humiliation renouncing all the human desires which is known by the conversation of Shakuntala with priest:

Priest: So many years of sacrifice and devotion, do you feel closer to self liberation? Shakuntala: If self liberation means detachment from worldly desires, then no, I am no closer.

Shakuntala's statement satires the religious dogmas of the widowhood culture which forwards the view that self liberation is attained by the detachment from the worldly desires. She expresses that she has not gained self liberation as described by the religion because she is still attached to the worldly desires and she seems to seek the self liberation in such worldly desires.

Widows are regarded as bad omen in the society. Moreover the shadow of the widows is regarded as an upcoming misfortune and bad luck in the society which is expressed by the dialogue of priest to Shakuntala as he says, "Watch it! Do not let your shadow touch the bride." When Shakuntala goes to the river to get holy water, on the very side of the river there is wedding ceremony going on. As she stops there to fill the pot with water, the ceremony comes to an abrupt halt. The priest sharply says her not to be present there as she is misfortune for a child bride who is just married. Lowering her eyes in humiliation and apology she goes back taking her pot.

In the middle part of the film, all widows come to the temple to listen the preaching of priest. Chuyia finds that all are women listening preach. She looks all women and priest and presumes that the white length of cloth in which they are wrapped in, is a uniform worn by both man and woman widows. She nudged Shakuntala and asks, "Didi, where is the house for male widows?" The line of Chuyia truly depicts that the tradition and culture are made in hierarchy order. Tradition and culture are the outcome of patriarchal norms and values which discriminates woman from man. Chuyia"s question about the house for widower is very just question in the sense that Hindu widow system imposes widows to live their lives in an ashram alienated from society but there is not any system made for men who are widower.

One of the duties of widow is to beg for money sitting outside the temple. Chuyia is not accustomed with such act of begging. One day she also goes with other widows and sits outside the temple. She does not know that she is there to beg money. In the very moment a woman and her daughter comes out from the temple. The young girl of her teens is in red sari and blouse. Chuyia seeing her remembers her red sari, blouse and bangles. She goes on seeing the mother and daughter, which make us feel that perhaps she is remembering her mother. The girl gives Chuyia a coin, and she (Chuyia) 
realizes that she is there to beg as beggar. Her hatred towards such culture of begging can be known by her action as she leaves the place saying, "I hate you", to Shakuntala.

Narayan, is a young and charming character of upper class, follower of Mahatma Gandhi falls in love with Kalyani on his very first sight. Upon meeting Kalyani there is a immediate attraction but the restriction placed on interaction with widows make it difficult to find a way of pursuing any kind of relationship. Kalyani feels insecure in presence of him as for widow; tradition does not allow her to talk to man. Kalyani prohibited by culture from addressing a stranger directly speak to Narayan through Chuyia and says, "Chuyia, tell him not to follow us. It will be sin."

Narayan begins to think about Kalyani and desires to get marry with her. Moreover, Kalyani on the other hand cannot get the young man (Narayan) out of her mind and begins to love him too in spite of knowing that to think of other man is sin. When Narayan asks Kalyani about her marriage and her husband she says, "I do not remember. I never met him." The line of Kalyani depicts that she does not remember her marriage which reveals to us that she was married in her teens. Though she does not remember her marriage ceremony and does not recognize her husband, she is following the culture of widowhood. Narayan says to her that he likes her and wants to marry her. Kalyani also likes him and wants to get married with him. Kalyani ignores social taboo by falling love with Narayan.

Mehta presents Kalyani as a revolutionary figure by making her to act against the widow system. The secret is revealed by Chuyia who is thrilled at the prospect of wedding feast where one can eat as many sweets and forbidden foods. When Madhumati forbids Chuyia from eating puri, Chuyia in her protest says," I will eat hundred puri in Kalyani's wedding." Madhumati comes to know through Chuyia that Kalyani is going to get married; she screams towards Chuyia and says "widows do not get married." Chuyia in her anger goes on saying, "Kalyani will get married. She will. She will. She will. Drown yourself, liar!"

Madhumati, after knowing Kalyani is going to get married, with rage goes towards the room of Kalyani and following conversation occurs between them:

Madhumati: Chuyia, says you are getting married?

Kalyani: Yes.

Madhumati: Have you gone mad? Nobody marries a widow.

Kalyani: He will.

Madhumati: Shameless! You will sink yourself and us. We all will be cursed. We must live in purity to die in purity.

The above dialogues between Madhumati and Kalyani depict that Madhumati is guided by orthodox tradition and religion, and regards that widows cannot marry; it will be great sin. But Kalyani tries to revolt such inhuman culture of religion by declaring that she is going to get married with Narayan. The saying of Madhumati about living in purity and die in purity truly explores the hypocrisy of Madhumati in the sense that on the one hand she talks about chastity and purity of widow on the other hand she sends Kalyani across the river to perform the act of prostitution in the house of bourgeois.

Kalyani raises question against Madhumati's act of sending her across the river for the act of prostitution. She expresses the double code of tradition imposed to her. Tradition does not allow her to re-marry and sets a belief that she must be faithful towards her dead husband by not having any physical relation with other man but it is the same tradition because of which she is sent across the river for the sexual fulfillment of the bourgeois. 
Chuyia thinks that widow house is not her house and her stay is temporary one. She will go to her house soon which is expressed in the following dialogues of Chuyia to Shakuntala:

Shakuntala: Don"t u have a dry sari?

Chuia: It is in your house.

Shakuntala: Bring it tomorrow.

Chuyia: Tomorrow, I will be in my house.

The dialogue of Chuyia expresses that widow house is Shakuntala's house. She does not want to accept the widow system that after her husband death, that ashram is her house. She lives in widow house in a illusion that one day she will go to her home.

After knowing Kalyani"s effort to violate the culture of widowhood, Madhumati locks her in the room. Moreover, she cuts her hair and says to other widows of the ashram, "We would have burned in hell because of her. I have saved you all!" Madhumati denies Kalyani's desire of getting remarried as she thinks it is against Hindu religion. Furthermore, she uses an abusive language to curse Kalyani which is expressed as, "Let's see the whore get married now."

The word whore here expresses about the treatment and use of language towards widows. Chuyia in her sadness asks Shakuntala to open the door. Shakuntala as a devout wife says, "To think about remarriage is sin." Chuyia asks the reason for denying Kalyani"s marriage and Shakuntala says, "Ask with God." Chuyia is a destabilizing force, questioning not only her own confinement but the logic of other widows.

Chuiya is the rebel who provides the voice for Mehta's broadside against the religious tradition of widowhood. Chuyia opens the cage to free the Mitthu. As soon as it becomes released she dies. It shows her protest against the prison like life of widows in the ashram such as Kalyani is locked inside the room. It seems that she is not only imprisoned in a room rather she is captive by the very traditional culture of Indian widowhood. There is a not alternative ahead of Mitthu like Kalyani who becomes free at first but her freedom causes her death at last. The death of a bird and Kalyani seems same. Both are helpless, marginalized in the society. Both are treated in a same way. People make Mitthu domestic by arresting its freedom and Kalyani too is used by the same people time to time as a prostitute.

The characters in a Bidhuwa Ashram are living a meager life. When Bua dies, there is not money for her cremation. Kalyani gives few coins to Shakuntala for the cremation of Bua. Moreover, Kalyani says, "Didi, I was saving these for my cremation." As women are not given any opportunity to work in economic field, they are living the poorest life by begging and often turning to prostitution, which is explicitly shown in the film. Corruption in ashram is shown by the event of Bua's funeral. Madhumati does not give money from the fund though she is head in the ashram. The money given by Seth in terms of Kalyani is misused by Madhumati.

Mehta shows the Indian culture of widowhood contrast to British culture. Once Narayan takes Kalyani in carriage for the tour of the city. In the very moment there comes the edge of the city, and he says that it is the very place where British lives. Kalyani feels insecure as tradition prohibits her to be with Narayan and if anyone recognizes her as a widow being with a man ( Narayan). Her face goes on dark as she is afraid, Narayan notices her and the following conversation occurs between them:

Narayan: They do not care if you are a widow. 
Kalyani: Why? Don"t they have widows?

Narayan: Of course they do. But not like ours; they do not treat them like we do.

The dialogue of Narayan reveals that there is not any system regarding widowhood in west in contrast to the east. In the dialogue the word "they"'means British and "our" means Indians. It does not matter for British if they see widows with man. Mehta's main purpose of bringing only reference of widowhood culture contrast to westerners" culture hints her critique of the treatment of Hindu widows which serves as a useful remainder to Indians for their need of a benevolent globalization from West.

\section{CONCLUSIONS}

Based on Feminist Theory, it is concluded that the film Water by Deepa Mehta presents the predicament of Indian Hindu widows. It shows the inert life of the group of widows obliged to live in a widow house neglected from society because of Hindu widow system; a cultural violation of the women identity in a society. Mehta shows how the characters have become the victim of the tradition and culture regarding widowhood as exemplified by the protagonists like Chuyia and Kalyani. Mehta criticizes the tradition regarding widowhood through her characters Chuyia and Kalyani. Mehta shows the possibility of subverting such culture of widowhood by raising the issue of widow marriage. Mehta shows her characters being suffered by the culture of widowhood as the consequent of such culture imparts the tragic end of the characters in the film.

\section{REFERENCES}

Altekar, A.S. The position of Women in Hindu Civilization. 2nd ed. New Delhi: Motilal Bonasidan, 1959.

Arnold, William. "Toward the Widows." Rev. of Water, dir. Deepa Mehta. The New York Times. 28 Apr. 2006: 5-7.

Beauvoir, Simone de. The Second Sex. New York: Vintage Books, 1974.

Catsoulis, Jeannette. " Under the Heel of Britain and the Thumb of Hindu Law in Water." Rev. of Water, dir. Deepa Mehta, The New York Times. 28 Apr. 2006: 19-20.

Forbes, Geraldina. The new Cambridge History of India. Ed. Gordan Johnson et al. Vol. 4.2. New Delhi: Manas Saikia for Foundation Books, 1998.

Hunter, Stephen. "Deepa Mehta's Water : The Depths of Despair." Washington post 5 May. 2006:C1.

Indira, M.K Phaniyamma. Trans. Tejaswini Nirajana. New Delhi: Kali for women, 1989.

Jamison, Stephanie and Joel Brereton. The Rigveda : The Earliest Religious Poetry of India, Oxford University Press, 2014.pp. 4 - 9

Kant, Anjana. Women and the Law. New Delhi: A.P.H publishing Corporation, 2003.

Mehta, Deepa. dir. Water. Dist. BR, 2006.

Narayan, Uma. Dislocating Cultures/ Identities, Traditions and Third World Feminism. New York: Routledge, 1997.

Paul, Suguna. "The Economics of Women's oppression." Women's oppression pattern and perspectives. Ed. Susheela Kaushik. Delhi: Sakti Books, 1986. 40-52.

Renavikar, Madhavi D. Women and Religion. New Delhi: Rawat Publications,1998.

Ruth, Sheila. Issues in Feminism. USA: Houghton Mifflin Company, 1990.

Sinha, Niroj. Women and Violence. New Delhi:Vikash Publishing house, 1989. 
International Journal of Management, Entrepreneurship, Social Science and Humanities (IJMESH), Vol. 3 (2), 37-49 Plight of Widows in Hindu Religion (A Social Critique To Deepa Mehata's Film Water)

Ramesh Prasad Adhikary

Spivak, Gayatri Chakravorty. "Can the Subaltern Speak?" Colonial Discourse and postcolonial Theory: A Reader. Ed. Patrick Williams and Laura Chrisman. New York: Columbia University Press, 1994. 66-111. 